\title{
Penilaian Integrasi Manajemen Risiko Bencana ke dalam Proses Penyusunan Rencana Tata Ruang Kota Surabaya
}

\author{
Naomi Zakina dan Adjie Pamungkas \\ Departemen Perencanaan Wilayah dan Kota, Fakultas Arsitektur, Desain dan Perencanaan \\ Institut Teknologi Sepuluh Nopember (ITS) \\ e-mail: adjie.difi@gmail.com
}

\begin{abstract}
Abstrak-UU 26/2007 menyebutkan bahwa rencana tata ruang di Indonesia terdiri dari dua rencana utama yaitu rencana umum dan rencana rinci tata ruang. Rencana tata ruang wilayah memuat akan strategi pengembangan Kota sedangkan rencana detail tata ruang menjadi referensi dalam aturan pengembangan kawasan lokal. Akibatnya, kegiatan pembangunan seperti pendirian bangunan, infrastruktur, dan fasilitas publik harus mengikuti aturan dari kedua rencana tersebut. Dalam konteks manajemen risiko bencana, pertumbuhan pembangunan mempengaruhi kerentanan dan kapasitas kota. Pembangunan yang tidak diimbangi dengan dengan upaya pengurangan risiko akan meningkatkan potensi kerentanan dan menurunkan kapasitas kota terhadap bencana. Dengan kata lain, hal ini mampu menurunkan ketahan kota dan meningkatkan risiko bencana. Selain itu, integrasi manajemen risiko bencana ke dalam rencana tata ruang bertujuan untuk menghindari risiko sekaligus memperkecil angka risiko tersebut. Penelitian ini akan menilai tentang integrasi manajemen risiko bencana ke dalam proses penyusunan rencana tata ruang Kota Surabaya. Pendekatan kualitatif menggunakan metode analisis konten dan skala likert dilakukan untuk menilai integrasi manajemen risiko bencana ke dalam proses penyusunan rencana tata ruang Kota Surabaya. Hasilnya, seluruh tahapan proses penyusunan rencana tata ruang -mulai dari perumusan masalah hingga monitoring dan evaluasi- belum mencerminkan upaya pengurangan risiko bencana secara rinci. Hal ini disebabkan oleh keterbatasan data dan informasi mengenai karakteristik bencana Kota Surabaya, perbedaan persepsi stakeholder dalam memandang aspek kebencanaan dalam proses pembangunan, pedoman penyusunan rencana tata ruang yang dianut belum terintegrasi dengan kajian manajemen risiko, dan belum ada mekanisme monitoring dan evaluasi yang sesuai terkait upaya pengurangan risiko bencana dalam rencana tata ruang.
\end{abstract}

Kata Kunci-Penilaian, Integrasi, Manajemen Risiko Bencana, Perencanaan Tata Ruang.

\section{PENDAHULUAN}

$\mathrm{I}_{\mathrm{k}}^{\mathrm{N}} \mathrm{m}$ NDONESIA merupakan negara kedua dengan jumlah kematian akibat bencana alam tertinggi se-Asia Pasifik [1]. Jumlah kerusakan materiil yang ditanggung Indonesia akibat bencana alam sejak 1900 hingga 2015 adalah sebesar 22.023,915 juta USD [2]. Disisi lain, Indonesia sedang aktif melakukan pembangunan. Tingginya pembangunan tanpa upaya pengurangan risiko bencana mampu meningkatkan indeks kerentanan dan menurunkan kapasitas pada suatu wilayah. Salah satu alat yang dapat digunakan untuk mengurangi risiko adalah rencana tata ruang [3].

Rencana tata ruang di Indonesia dapat dikelompokkan memiliki dua berdasarkan skala wilayah dan kedetailan substansinya, yaitu rencana umum dan rencana detail tata ruang [4], [5]. Rencana umum memuat arahan strategis pemanfaatan ruang pada wilayah yang luas sedangkan rencana detail memuat informasi mengenai aturan zonasi, pengembangan infrastruktur dan fasilitas umum lainnya. Dalam upaya pengurangan risiko bencana, rencana tata ruang berperan dalam mengatur pola ruang dan struktur ruang yang mampu mengurangi kerentanan dan meningkatkan kemampuan di suatu wilayah. Peran rencana tata ruang ini misalnya berupa pembatasan pembangunan pada kawasan dengan risiko bencana tinggi dan penentuan building codes [6]. Salah satu contoh kota dengan potensi bencana yang cukup tinggi adalah Kota Surabaya.

Kota Surabaya memiliki kerentanan tinggi terhadap empat jenis bencana yaitu banjir, kebakaran, angin puting beliung dan kerentanan tanah [7]. Banjir di Kota Surabaya terdiri atas banjir rob di kawasan pesisir pantai Surabaya dan genangan air pada saat musim penghujan. Luas, kedalaman, dan durasi genangan di Kota Surabaya mengalami penurunan signifikan selama tahun 2005 hingga 2016. Namun saat terjadi hujan lebat, kawasan permukiman Wiyung seluas $127 \mathrm{Ha}$ mengalami genangan dengan ketinggian $30 \mathrm{~cm}$ selama 40 menit serta kerugian Pemerintah mencapai 31 juta rupiah [8]. Kebakaran merupakan bencana dengan frekuensi kejadian tertinggi dan menimbulkan kerugian yang signifikan terhadap perkembangan Kota Surabaya. Data Dinas Kebakaran Kota Surabaya mencatat pada tahun 2015 terjadi 609 kasus dengan kerugian material sebesar 13.179 juta rupiah serta 8 korban meninggal dan 29 korban luka. Untuk bencana angin puting beliung, data BPBL Kota Surabaya menunjukkan jumlah kejadian bencana pada tahun 2015 sebesar 28 kali, yang mengalami kenaikan dibandingkan tahun sebelumnya yaitu 11 kali kejadian pada tahun 2014.

Kemudian berdasarkan kajian PUSGEN (Pusat Gempa Nasional), ditemukan potensi sumber gempa tektonik baru dengan kekuatan mencapai 6,5 SR dari pergerakan Sesar Kendeng di sisi selatan Surabaya [9]. Rata-rata gerakan sesar Kendeng diperkirakan sebesar $0,5 \mathrm{~cm} /$ tahun dengan tingkat klasifikasi bahaya rendah hingga sedang. Selain itu, sebagian besar wilayah Kota Surabaya berada pada kategori tingkat amplifikasi tanah sedang hingga tinggi [10]. Hal ini menyebabkan potensi risiko gempa bumi berada pada klasifikasi sedang hingga tinggi dan mampu mengancam pembangunan kota [11].

Dengan laju pembangunan di Kota Surabaya cukup pesat dilihat dari luas lahan terbangun eksisting maupun jumlah usulan izin pendirian bangunan dan potesi risiko bencana yang relatif tinggi, diperlukan rencana tata ruang yang sensitif terhadap upaya pengurangan risiko. Oleh karena itu, penelitian ini akan mencari integrasi manajemen risiko bencana ke dalam proses penyusunan rencana tata ruang Kota Surabaya agar terwujud pembangunan kota yang berketahanan (resilience). 
Tabel 1.

Responden penelitian

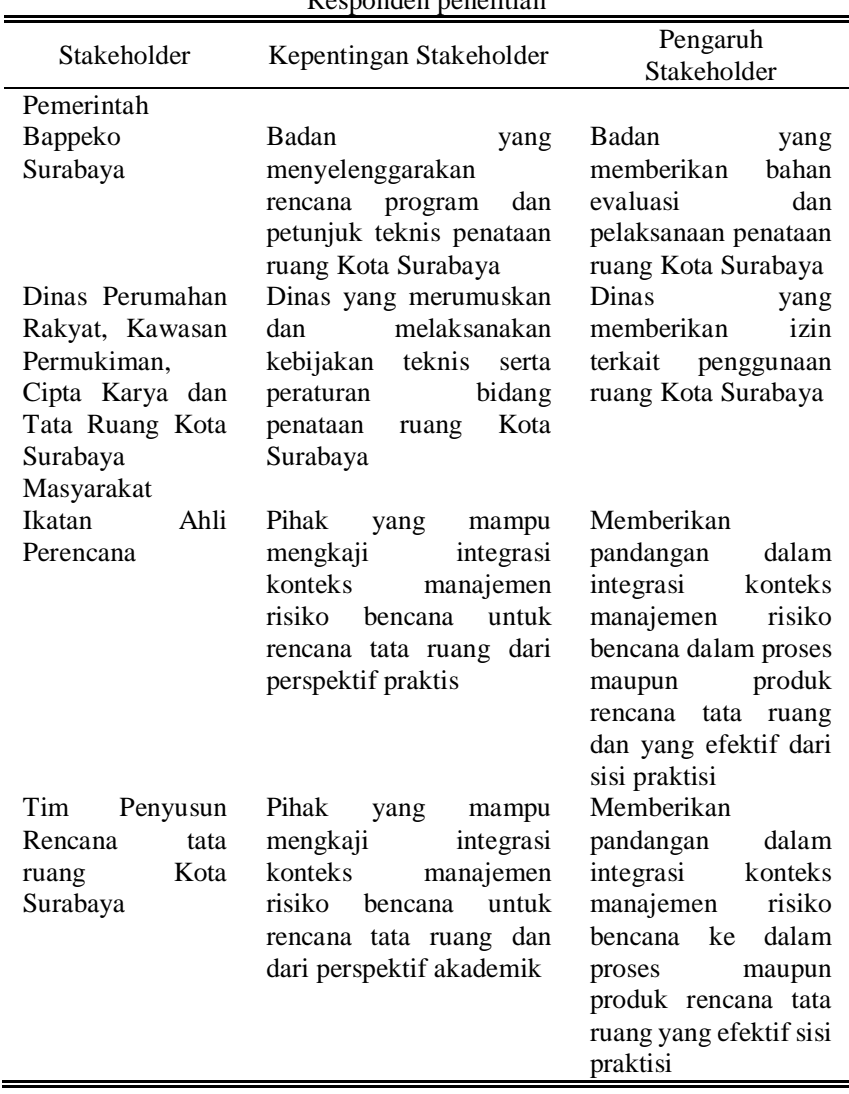

\section{METODE PENELITIAN}

\section{A. Jenis dan Pendekatan Penelitian}

Jenis penelitian ini adalah kualitatif. Adapun pendekatan yang digunakan dalam penelitian ini adalah pendekatan rasionalistik [12].

\section{B. Variabel Penelitian}

Variabel penelitian yang digunakan untuk menilai integrasi manajemen risiko bencana ke dalam proses penyusunan rencana tata ruang Kota Surabaya antara lain perumusan masalah, perumusan tujuan, pengumpulan data, analisis data, penyusunan alternatif rencana tata ruang, penetapan rencana tata ruang, implementasi, monitoring dan evaluasi.

\section{Mengidentifikasi Variabel Penilaian Integrasi} Manajemen Risiko Bencana ke dalam Proses Penyusunan Rencana Tata Ruang Kota Surabaya menggunakan Studi Literatur

Studi literatur ini dilakukan dengan mengkompilasi teori yang diambil dari buku, jurnal, regulasi atau publikasi lain yang berhubungan dengan manajemen risiko bencana (MRB), konsep ketahanan (recilience), prinsip mengevaluasi kebijakan publik dan perencanaan tata ruang. Luaran dari proses tersebut berupa variabel dan kriteria nilai integrasi manajemen risiko bencana ke dalam rencana tata ruang. Variabel ini dianggap telah valid dan mampu digunakan untuk proses analisis berikutnya.

D. Menilai Integrasi Manajemen Risiko Bencana ke dalam Proses Penyusunan Rencana Tata Ruang Kota Surabaya

Penilaian integrasi manajemen risiko bencana ke dalam proses penyusunan rencana tata ruang Kota Surabaya pada penelitian ini menggunakan pendekatan kualitatif dengan alat

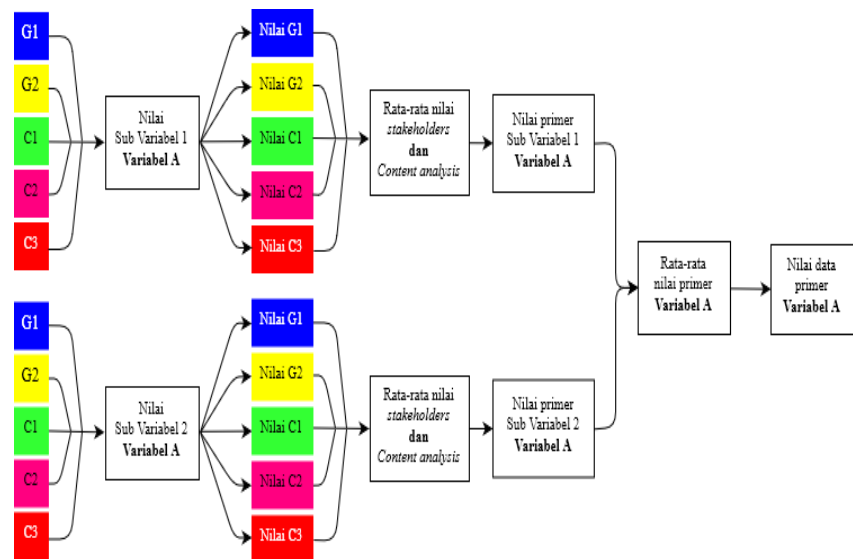

Gambar 1. Proses penilaian data primer integrasi manajemen risiko bencana ke dalam proses penyusunan rencana tata ruang Kota Surabaya kepada responden.

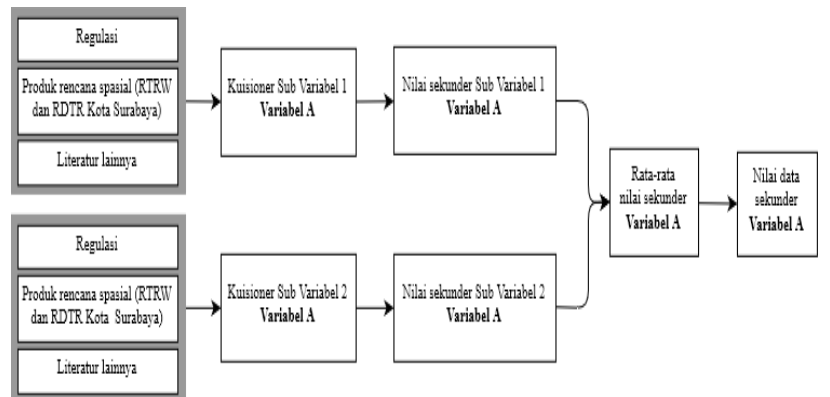

Gambar 2. Proses penilaian data sekunder integrasi manajemen risiko bencana ke dalam proses penyusunan rencana tata ruang Kota Surabaya.

ukur skala likert yang divalidasi dengan Analisis Konten. Proses penilaian ini terbagi menjadi tiga tahapan berikut :

1. Menganalisis stakeholder untuk menemukan responden penelitian metode purposive sampling berdasarkan kompetensi dan keterlibatan responden dalam proses penyusunan rencana tata ruang Kota Surabaya. Stakeholder yang terpilih sebagai responden penelitian ditunjukkan pada Tabel 1.

2. Melakukan in-depth-interview berbentuk diskusi dengan responden untuk menggali informasi terkait nilai primer dan menelaah literatur, regulasi dll untuk mendapatkan referensi nilai sekunder. Proses in-depth-interview dilakukan melalui kuisioner terstruktur yang terdiri atas nilai dengan skala likert 1-5 dan kriteria untuk setiap poin likert. Semakin besar nilainya, maka semakin baik kondisi integrasinya. Hal ini juga berlaku pada kondisi sebaliknya (Gambar 1).

3. Menghitung nilai data primer untuk mendapatkan nilai integrasi menurut responden. Nilai menurut responden disajikan dalam tabel kemudian divalidasi menggunakan analisis konten dari hasil percakapan selama proses indepth-interview. Hal ini dilakukan untuk memaknai dan memperkuat nilai tersebut. Selanjutnya, seluruh nilai responden di rata-rata sehingga didapatkan nilai final data primer dan deskripsinya (Gambar 2).

4. Menghitung nilai data sekunder untuk mendapatkan nilai menurut literatur (ketersedaiaan data eksisting pada buku, laporan kinerja lembaga, dokumen produk rencana tata ruang, dll). Langkah perhitungan nilai data sekunder hampir sama dengan proses perhitungan nilai data primer. Perbedaannya adalah penilaian data sekunder dilakukan terhadap buku, laporan kinerja instansi, regulasi dll. Ini dilakukan untuk melengkapi data primer dan mengurangi 
tingkat subyektif nilai pada proses sebelumnya sehingga menghasilkan data yang baik (Gambar 3).

5. Menghitung rata-rata nilai data primer dan data sekunder untuk mendapatkan nilai final integrasi manajemen risiko bencana ke dalam rencana tata ruang Kota Surabaya.

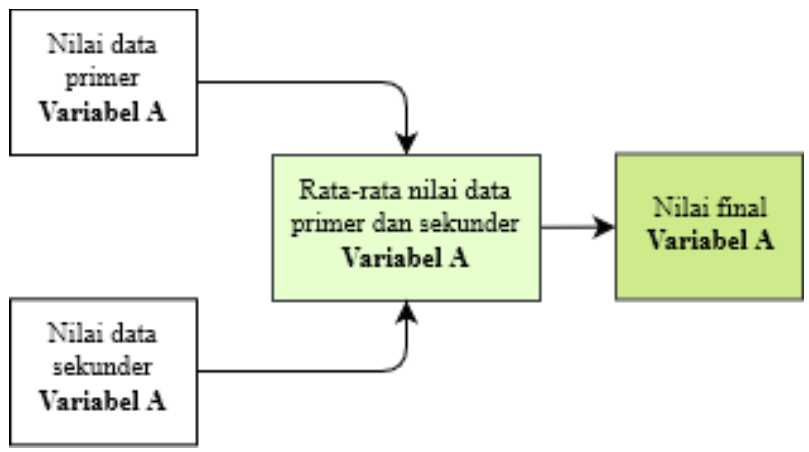

Gambar 3. Proses penilaian final integrasi manajemen risiko bencana ke dalam proses penyusunan rencana tata ruang Kota Surabaya

\section{E. Merumuskan Arahan Integrasikan Manajemen Risiko Bencana ke dalam Proses Penyusunan Rencana Tata Ruang Kota Surabaya}

Arahan integrasi manajemen risiko bencana ke dalam proses penyusunan rencana tata ruang dilakukan dengan membandingkan kondisi eksisting dengan target ideal proses penyusunan rencana tata ruang berbasis manajemen risiko.

\section{HASIL DAN DISKUSI}

A. Mengidentifikasi Variabel Penilaian Integrasi Manajemen Risiko Bencana ke dalam Proses Penyusunan Rencana Tata Ruang Kota Surabaya menggunakan Studi Literatur

Berdasarkan hasil studi literatur didapatkan variabel dan kriteria penilaian integrasi manajemen risiko bencana ke dalam proses penyusunan rencana tata ruang Kota Surabaya. Variabel tersebut dapat dilihat pada Tabel 2.

\section{B. Menilai Integrasi Manajemen Risiko Bencana ke dalam Proses Penyusunan Rencana Tata Ruang Kota Surabaya}

Nilai integrasi manajemen risiko bencana dalam proses penyusunan rencana tata ruang Kota Surabaya dapat dilihat dalam gambar 2.

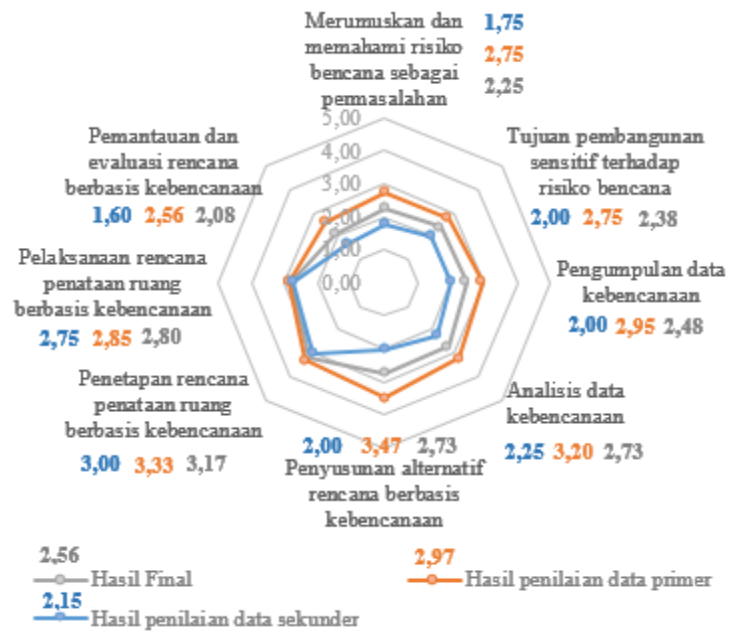

Gambar 2. Nilai final integrasi manajemen risiko bencana ke dalam proses penyusunan rencana tata ruang Kota Surabaya.
Tabel 2.

Variabel penilaian integrasi manajemen risiko bencana ke dalam proses penyusunan rencana tata ruang Kota Surabaya

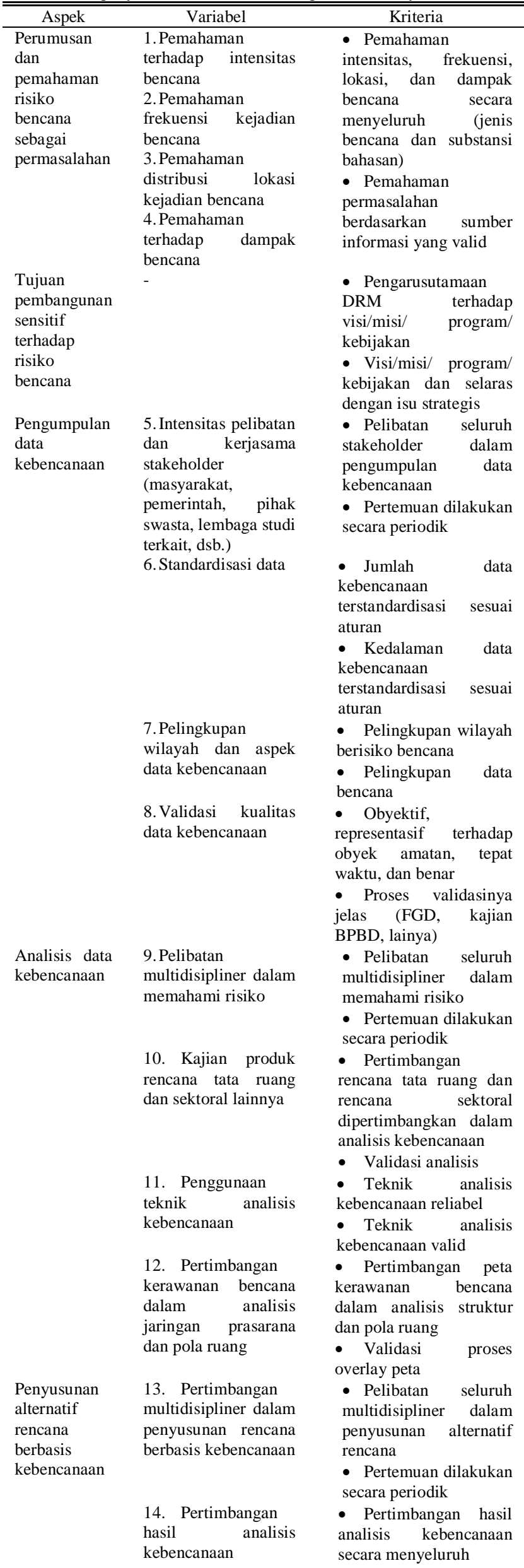


15. Validasi proses penyusunan alternatif rencana berbasis kebencanaan

Penetapan $\begin{aligned} & \text { 16. Persetujuan } \\ & \text { rencana tata } \\ & \text { ruang }\end{aligned}$
beluruh pihak
kebencanaan

17. Kemampuan rencana dalam memvisualisasikan pembangunan kota di masa depan

18. Pengajuan legalitas produk rencana penataan ruang berbasis kebencanaan

Pelaksanaan 19. Pelibatan rencana tata stakeholders ruang kebencanaan

berbasis

kebencanaan

20. Kemudahan akses informasi rencana pengurangan risiko

21. Koordinasi dan komunikasi antar pelaku selama proses implementasi rencana pengurangan risiko bencana

22. Penggunaan

RTRW sebagai pedoman pengurangan risiko bencana

Pemantauan 23. Efektifitas

dan evaluasi rencana pengurangan rencana

berbasis

kebencanaan

risiko bencana

24. Kecukupan

upaya peningkatan

kapasitas dalam mengurangi risiko bencana

\section{Pemerataan \\ biaya dan manfaat tindakan \\ pengurangan risiko kepada kelompok masyarakat \\ 26. Responsifitas \\ rencana terhadap \\ kepuasan publik \\ 27. Ketepatan \\ rencana dalam mengurangi risiko bencana}

Nilai final integrasi manajemen risiko bencana dalam proses penyusunan rencana tata ruang Kota Surabaya sebesar 2,56 dari poin maksimal 5. Ini artinya, integrasi tersebut berada pada posisi buruk hingga cukup baik. Variabel dengan performa terbaik ialah tahap penetapan rencana penataan ruang berbasis kebencanaan $(3,17)$ sedangkan variabel dengan performa terburuk ialah tahap perumusan dan pemahaman risiko bencana sebagai permasalahan serta tahap pemantauan dan evaluasi rencana berbasis kebencanaan $(2,08)$.

Dari proses penilaian tersebut, ditemukan perbedaan hasil penilaian data primer dan hasil penilaian data sekunder sebesar 0,82 poin. Artinya terjadi kondisi over-confident pada responden yang menganggap bahwa seluruh proses penyusunan rencana tata ruang Kota Surabaya telah memperhatikan risiko bencana dengan baik. Hal ini perlu diantisipasi agar rencana tata ruang Kota Surabaya mampu mengakomodir kebutuhan dan tantangan pengurangan risiko secara komprehensif.

Penyebab rendahnya nilai integrasi manajemen risiko bencana dalam proses penyusunan rencana tata ruang Kota Surabaya adalah keterbatasan data dan informasi yang rinci mengenai frekuensi kejadian, intensitas, distribusi lokasi dan dampak kejadian untuk setiap jenis bencana. Seluruh responden mengatakan jika informasi tersebut belum tersedia. Informasi mengenai bencana Kota Surabaya terbatas pada jenis bencana banjir/genangan dan kebakaran [13].

Selain itu, keterbatasan informasi mengenai karakteristik bencana mempengaruhi persepsi stakeholder memandang urgensi aspek kebencanaan dalam proses pembangunan. Responden berpendapat jika potensi bencana Kota Surabaya -banjir/ genangan dan kebakaran- bukan tergolong dalam bencana yang menimbulkan dampak signifikan terhadap kota, seperti gempa atau tanah longsor. Oleh karena itu, upaya pengurangan risiko tidak tertuang secara eksplisit, detail dan menyeluruh -untuk setiap jenis bencana- dalam tujuan rencana tata ruang Kota Surabaya.

Pengarusutamaan manajemen risiko bencana ke dalam rencana tata ruang merupakan hal baru di Indonesia [14]. Permen PU 17/2009 tentang Pedoman Penyusunan RTRW Kota dan Permen PU 20/2011 tentang Pedoman Penyusunan RDTR belum memprioritaskan isu bencana dan upaya pengurangan risiko bencana dalam proses penyusunan rencana tata ruang. Aspek kajian risiko dan standar data kebencanaan belum termuat dalam proses pengumpulan dan analisis data rencana tata ruang. Dengan demikian, perlu adanya integrasi antar regulasi khususnya mengenai pedoman penyusunan rencana tata ruang dengan pedoman umum pengkajian risiko bencana.

Melalui hasil in-depth-interview, ditemukan jika belum ada pelibatan multidisipliner yang spesifik untuk menangani seluruh jenis bencana dalam proses penyusunan alternatif rencana tata ruang berbasis kebencanaan Kota Surabaya. Pernyataan tersebut sesuai dengan kutipan berikut :

Indikasi lain yang ditemukan selama proses in-depthinterview adalah inkonsistensi individu yang bertanggungjawab mengawal proses konsultasi publik menyebabkan informasi yang tersampaikan bersifat parsial. Konsultasi publik adalah proses dialog dan/atau diskusi dimana seluruh pemangku kepentingan diundang untuk memvalidasi data, proses analsis dan hasil rencana yang telah disusun. Tahap ini dilakukan sebanyak dua kali yaitu saat perumusan rencana tata ruang dan saat pembahasan rancangan peraturan daerah (raperda) tentang rencana tata ruang [15], [16].

Terakhir, ditemukan bahwa belum ada mekanisme monitoring dan evaluasi yang sesuai terkait upaya pengurangan risiko bencana dalam rencana tata ruang. Menurut responden proses evaluasi hanya dilakukan melalui pendekatan capaian indikasi program pembangunan yang ada dalam rencana tata ruang. 


\section{KESIMPULAN}

Dihasilkan 28 variabel dan kriteria yang relevan untuk menilai integrasi manajemen risiko bencana ke dalam proses penyusunan rencana tata ruang Kota Surabaya. Seluruh variabel tersebut dikelompokkan berdasarkan tahapan proses penyusunan rencana tata ruang wilayah.

Berdasarkan hasil penilaian, integrasi manajemen risiko bencana dalam proses penyusunan rencana tata ruang Kota Surabaya sebesar 2,56 dari poin maksimal 5. Ini artinya, integrasi tersebut berada pada posisi buruk hingga cukup baik.

Penyebab rendahnya nilai integrasi manajemen risiko bencana dalam proses penyusunan rencana tata ruang Kota Surabaya antara lain keterbatasan data dan informasi yang rinci mengenai frekuensi kejadian, intensitas, distribusi lokasi dan dampak kejadian untuk setiap jenis bencana, perbedaan persepsi stakeholder yang memandang bahwa aspek kebencanaan bukan sebagai aspek utama dalam proses pembangunan, belum terintegrasinya pedoman penyusunan rencana tata ruang dengan pedoman umum pengkajian risiko bencana, belum ada pelibatan multidisipliner yang spesifik untuk menangani seluruh jenis bencana dalam proses penyusunan alternatif rencana tata ruang berbasis kebencanaan, adanya inkonsistensi individu yang bertanggungjawab mengawal proses konsultasi publik menyebabkan informasi yang tersampaikan bersifat parsial, dan belum ada mekanisme monitoring dan evaluasi yang sesuai terkait upaya pengurangan risiko bencana dalam rencana tata ruang.

Hasil penilaian integrasi manajemen risiko bencana ke dalam proses penyusunan rencana tata ruang pada penelitian ini dilakukan untuk mengeksplorasi kondisi di lokasi penelitian. Oleh karena itu, perlu dilakukan pengembangan penelitian pada lokasi berbeda sehingga didapatkan tingkat capaian integrasi tersebut dapat dikomparasikan. Selanjutnya, hasil komparasi tersebut dapat digunakan untuk memperbaiki rencana tata ruang untuk mewujudkan kota berketahanan bencana.

\section{DAFTAR PUSTAKA}

[1] M. C. Ulum, "Governance dan Capacity Building dalam Manajemen Bencana Banjir di Indonesia," J. Penanggulangan Bencana, vol. 4, no. 2, pp. 5-12, 2013.

[2] EM-DAT, "The International Disaster Database," Centre for Research on the Epidemiology of Disasters. 2015.

[3] UNISDR, "Hyogo Framework for Action 2005- 2015 : Building the Resilience of Nations and Communities to Disasters," 2005.

[4] Presiden Republik Indonesia; Dewan Perwakilan Rakyat Republik Indonesia, Undang-Undang RI No 26 Tahun 2007 tentang Penataan Ruang. Indonesia, 2007, p. 107.

[5] H. Sutanta, A. Rajabifard, and I. D. Bishop, "Integrating Spatial Planning and Disaster Risk Reduction at the Local Level in the Context of Spatially Enabled Government," Spat. Enabling Soc. Res. Emerg. Trends Crit. Assess., pp. 2015-218, 2010.

[6] R. J. Burby and S. P. French, "Coping with floods the land use management paradox," J. Am. Plan. Assoc., vol. 47, no. 3, pp. 289300,1981

[7] W. SURABAYA, Peraturan Daerah Kota Surabaya Nomor 10 Tahun 2016 tentang RPJMD Kota Surabaya Tahun 2016-2021. Indonesia, 2016, pp. 1-646.

[8] U. Lasminto, "Evaluasi Genangan Kota Surabaya," in Prosiding Seminar Nasional Aplikasi Teknologi Prasarana Wilayah (ATPW), 2015, pp. 83-98.

[9] I. Meilano et al., "Evidence of Kendeng thrust activity from geodetic observation," 2016.

[10] W. Utama, "Aplikasi Fuzzy Pada Otomatisasi Microzonasi Kegempaan Wilayah Permukiman Padat (Studi Kasus: Kota Surabaya)," Surabaya, 2011.

[11] A. Solikhin, "Bahaya Gempa Bumi \& Tsunami di Provinsi Jawa Timur," 2016.

[12] N. Muhadjir, Metodologi Penelitian Kualitatif: Pendekatan Positivisma, Rasionalistik, Phenomenologik, Realism Metaphisik, Telaah Studi Teks dan Penelitian Agama. Yogyakarta: Rake Sarasin, 1996

[13] W. Surabaya, Peraturan Daerah Kota Surabaya Nomor 12 Tahun 2014 tentang Rencana Tata Ruang Wilayah Kota Surabaya Tahun 2014-2034, vol. 1965. Indonesia, 2014, pp. 1-173.

[14] A. Pamungkas and D. Iranata, "Building Urban Resilience to Earthquake in Surabaya Through Development Regulations," Surabaya, 2017.

[15] K. P. Umum, Peraturan Menteri Pekerjaan Umum Nomor: 17/Prt/M/2009 Tentang Pedoman Penyusunan Rencana Tata Ruang Wilayah Kota. Indonesia, 2009, pp. 1-74.

[16] K. P. Umum, Peraturan Menteri Pekerjaan Umum Nomor: 20/PRT/M/2011 tentang Pedoman Penyusunan Rencana Detail Tata Ruang dan Peraturan Zonasi Kabupaten/Kota. Indonesia, 2011, pp. 1-161. 